\title{
PENGENDALI OTOMASI 3-AXIS BERBASIS PC PADA SIMULASI PROSES LAS
}

\author{
Puji Hartono dan Muhammad Nauval Fauzi \\ Balai Besar Logam dan Mesin, Kementerian Perindustrian \\ Jl. Sangkuriang No.12, Bandung, Jawa Barat, 40135 \\ Email: nauval@kemenperin.go.id / nauva1911@gmail.com
}

\begin{abstract}
Abstrak
Proses pengelasan manual memiliki beberapa kekurangan diantaranya adalah hasil yang kurang homogen dan kuantitas hasil yang terbatas. Pada produksi masal yang membutuhkan kualitas dan kuantitas yang baik, terlebih lagi pada produksi yang harus mengejar kapasitas produksi tertentu tetapi terbatas waktunya, Hal tersebut menjadi latar belakang dilakukannya penelitian ini. Tujuan penelitian ini yaitu untuk meningkatkan kualitas dan kuantitas produksinya tanpa terbatasnya waktu, salah satunya dengan cara melakukan proses otomasi, yakni dengan simulasi pada proses las menggunakan robot 2-axis atau lebih. Dalam penelitian ini, menggunakan metodologi pengendali otomasi 3-axis berbasis PC (Personal Computer) dengan menggunakan robot 3-axis yang dikendalikan dengan 3 buah motor stepper, dimana motor stepper tersebut secara hardware dikendalikan oleh driver motor stepper HY-TB3DV-M yang mampu mengendalikan motor sampai 3,5 Ampere. Selain itu, digunakan pula software Mach3 dan EMC2, kedua software tersebut menerima masukan G-Code yang akan diterjemahkan ke dalam robot 3-axis. Hasil penelitian ini bahwa robot 3-axis dapat melakukan gerakan-gerakan seperti yang ada pada proses pengelasan seperti gerakan zig-zag dan gerakan lainnya sesuai dengan $G$-Code yang dimasukkan ke software seperti yang terlihat dalam simulasi pada proses las. Kode "G-CODE" dapat melakukan semua gerakan berbasis 3-axis. Pengendali otomasi 3-axis menggunakan software berbasis PC ini sebagai alternatif pengganti kontrol unit yang harganya mahal.
\end{abstract}

Kata Kunci : Pengendali otomasi, Otomasi 3-axis, Simulasi proses las, otomasi berbasis PC

\begin{abstract}
Manual welding process has some shortages which are the result of a less homogeneous and limited results quantity. In mass production requires both quality and quantity, especially in pursuing production capacity of certain production in limited time. It became the background of this research. The purpose of this research is to improve the quality and quantity of the production without limited time, amongst it by process automation, such as welding process simulation using a 2-axis or more axis robot. The research's method is PC-based for pilot automation welding process is performed using 3-axis robots which are controlled by three stepper motors, where the stepper motor's hardware is controlled by stepper motor driver HY-TB3DV-M that is capable of controlling motors up to 3.5 Ampere. Other than that, Mach3 and EMC2 software were used where both of the software received input G-Code that will translate into 3-axis robots. The research result showed that 3-axis robot can perform movements such as the welding process which is zigzag movements and other movements in accordance with G-Code that entered into the software like been shown in welding process simulation. "G-CODE" codes can do all 3-axis motion based. 3-axis automation using a PC-based software can be used as an alternative to the expensive control unit.
\end{abstract}

Keywords : Pilot automation, 3-axis automation, Welding process simulation, PC-based automation

\section{PENDAHULUAN}

Pada proses pengelasan pada umumnya dilakukan secara manual yaitu secara teknis dilakukan oleh orang dengan menggunakan tangan. Proses las manual memiliki beberapa kekurangan, seperti:

1. Hasil pengelasan tidak homogen.

2. Proses pengelasan waktunya sangat terbatas (tidak dapat bekerja 24 jam sehari). sehingga untuk produksi massal menyebabkan kapasitas produksinya terbatas dan juga pada proses repair yang menggunakan teknis las, memang pada umumnya menggunakan las-las manual, akan tetapi pada proses produksi massal yang melibatkan proses las, diperlukan otomasi las sehingga kualitas dan kuantitas produksinya meningkat. Kontrol unit pada mesin otomasi dapat diganti dengan PC biasa yang di install softwere otomasi sehingga biayanya lebih murah. 


\section{TINJAUAN PUSTAKA Otomasi $^{(5),(10)}$}

Teknik otomasi adalah teknik dalam penggunaan mesin, sistem control dan teknologi informasi untuk optimaliisasi produksi dan pengiriman barang dan jasa. Adapun Otomasi hanya dilakukan jika hasilnya lebih cepat, lebih baik secara kuantitas atau kualitas dibandingkan dengan penggunaan tenaga kerja manusia. Dalam dunia industri, otomasi merupakan lanjutan dari mekanisasi, dimana mekanisasi masih membutuhkan operator manusia selama mesin beroperasi. Otomasi mengurangi peran manusia dalam hal tersebut.

\section{Sistem Koordinat Kartesius ${ }^{(4)}$}

Dalam Matematika, suatu sistem koordinat Kartesius pada umumnya digunakan untuk menentukan tiap titik dalam bidang dengan menggunakan dua bilangan yang biasa disebut koordinat $\mathrm{x}$ dan koordinat $\mathrm{y}$ dari titik tersebut. Untuk mendefinisikan koordinat diperlukan dua garis berarah yang tegak lurus satu sama lain (sumbu $\mathrm{x}$ dan sumbu $\mathrm{y}$ ), dan panjang unit, yang dibuat tanda-tanda pada kedua sumbu tersebut, lihat gambar dibawah ini :

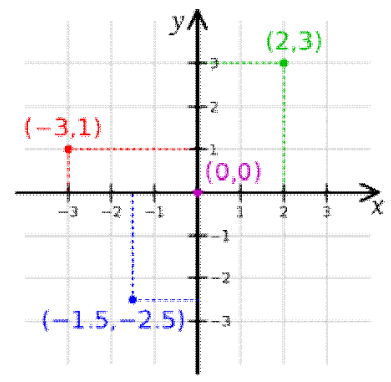

Gambar 1. Sistem Koordinat Kartesius yang mempunyai koodinat $\mathrm{x}(2,3)$ titik hijau, koodinat $\mathrm{y}$ $(-3,1)$ titik merah, dan dua garis berarah tegak lurus satu sama lain $(-1,5,-2.5)$ panjang unit titik biru dan titik asal $(0,0)$ berwarna ungu.

Istilah Kartesius tersebut digunakan untuk mengenang ahli Matematika sekaligus filsuf dari Perancis Descartes, yang sangat berperan besar dalam menggabungkan aljabar dan geometri (Cartesius adalah latinisasi untuk Descartes). Hasil kerjanya sangat berpengaruh dalam perkembangan geometri analitik, kalkulus dan kartografi.

Ide dasar sistem ini dikembangkan pada tahun 1637 dalam dua tulisan karya Descartes. Pada bagian kedua dari tulisannya Discourse on Method, ia memperkenalkan ide baru untuk menggambarkan posisi titik atau obyek pada sebuah permukaan, dengan menggunakan dua sumbu yang bertegak lurus antar satu dengan yang lain. Sedangkan dalam tulisannya yang lain, La Géométrie, ia memperdalam konsep-konsep yang telah dikembangkannya tersebut.

Dengan menggunakan sistem koordinat Kartesius, bentuk-bentuk geometri seperti pada kurva dapat diekspresikan dengan persamaan aljabar. Sebagai contoh, lingkaran yang berjarijari 2 dapat diekspresikan dengan persamaan $\mathrm{x}^{2}+\mathrm{y}^{2}=4$, lihat gambar di bawah ini:

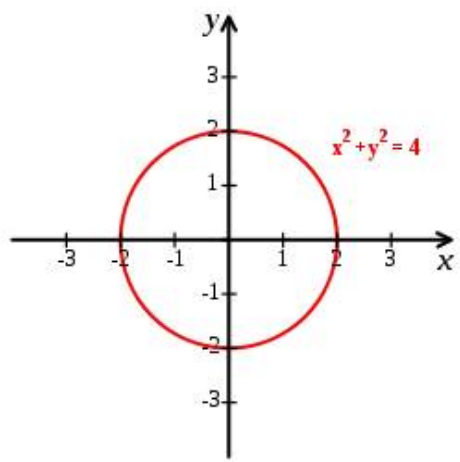

Gambar 2. Sistem koordinat Kartesius pada lingkaran merah yang berjari-jari 2 yang berpusat pada titik asal $(0,0)$

Persamaan lingkarannya adalah $x^{2}+y^{2}=4$.

\section{Sistem Motor Stepper ${ }^{(1),(2)}$}

Motor Stepper adalah suatu motor listrik yang dapat mengubah pulsa listrik yang diberikan menjadi gerakan motor discret (terputus) yang disebut step (langkah). Satu putaran motor memerlukan $360^{\circ}$ dengan jumlah langkah yang tertentu perderajatnya. Ukuran kerja dari motor stepper biasanya diberikan dalam jumlah langkah per-putaran per-detik.

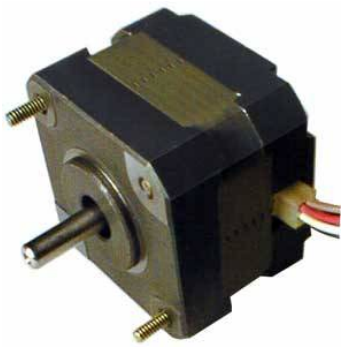

Gambar 3. Contoh gambar Motor Stepper

Motor stepper bergerak berdasarkan urutan pulsa yang diberikan kepada motor . Karena itu, untuk menggerakkan motor stepper diperlukan pengendali motor stepper yang membangkitkan pulsa-pulsa periodik. Pada dasarnya terdapat tiga (3) tipe motor stepper yaitu:

1. Motor Stepper Tipe Variable Reluctance (VR). Motor stepper jenis ini telah lama ada dan merupakan jenis motor yang secara struktural paling mudah untuk dipahami. Motor ini terdiri atas sebuah rotor besi lunak 
dengan beberapa gerigi dan sebuah lilitan stator. Ketika lilitan stator diberi energi dengan arus DC, kutub-kutubnya menjadi termagnetasi. Perputaran terjadi ketika gigigigi rotor tertarik oleh kutub-kutub stator. Berikut ini adalah penampang melintang dari motor stepper tipe variable reluctance (VR):

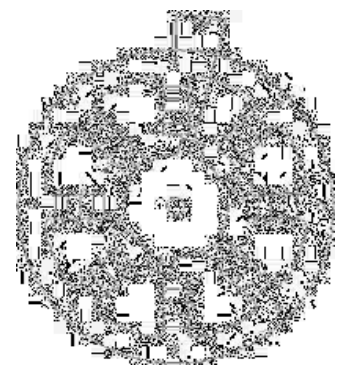

Gambar 4. Contoh gambar penampang melintang motor stepper pada tipe variable reluctance (VR)

2. Motor Stepper Tipe Permanent Magnet (PM). Motor stepper jenis ini memiliki rotor yang berbentuk seperti kaleng bundar (tin can) yang terdiri atas lapisan magnet permanen yang diselang-seling dengan kutub yang berlawanan. Dengan adanya magnet permanen, maka intensitas fluks magnet dalam motor ini akan meningkat sehingga dapat menghasilkan torsi yang lebih besar. Motor jenis ini biasanya memiliki resolusi langkah (step) yang rendah yaitu antara $7,5^{\circ}$ hingga $15^{\circ}$ per langkah atau 48 hingga 24 langkah setiap putarannya. Berikut ini adalah ilustrasi sederhana dari motor stepper tipe permanent magnet:

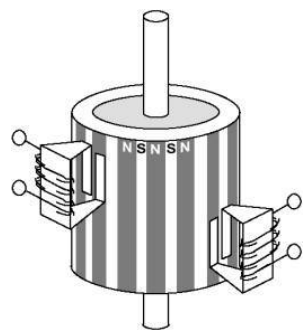

Gambar 5. Contoh gambar Ilustrasi motor stepper permanent magnet (PM)

3. Motor Stepper Tipe Hybrid (HB). Motor stepper tipe hibrid memiliki struktur yang merupakan kombinasi dari kedua tipe motor stepper sebelumnya. Motor stepper tipe hibrid memiliki gerigi seperti pada motor tipe VR dan juga memiliki magnet permanen yang tersusun secara aksial pada batang porosnya seperti motor tipe PM. Motor tipe ini paling banyak digunkan dalam berbagai aplikasi karena kinerja lebih baik. Motor tipe hibrid dapat menghasilkan resolusi langkah yang tinggi yaitu antara $3,6^{\circ}$ hingga $0,9^{\circ}$ per-langkah atau $100-400$ langkah setiap putarannya.

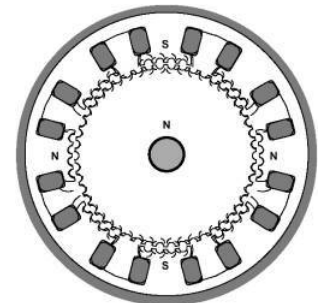

Gambar 6. Contoh gambar penampang melintang dari motor stepper tipe hybrid

Berdasarkan metode perancangan rangkain pengendali motor stepper, motor stepper dapat dibagi menjadi jenis yaitu unipolar dan bipolar:

- Motor Stepper Jenis Unipolar. Rangkaian pengendali motor stepper unipolar lebih mudah dirancang karena hanya memerlukan satu switch/transistor pada setiap lilitannya. Untuk menjalankan dan menghentikan motor ini cukup dengan menerapkan pulsa digital yang hanya terdiri atas tegangan positif dan nol (ground) pada salah satu terminal lilitan (wound) motor, sementara terminal lainnya dicatu dengan tegangan positif konstan (VM) pada bagian tengah (center tap) dari lilitan.

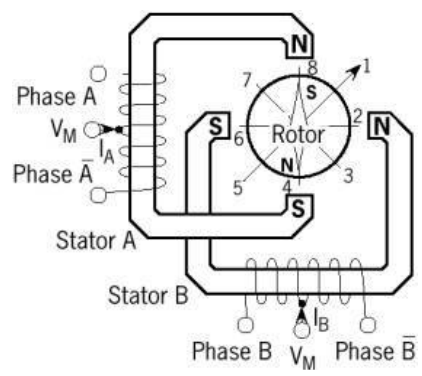

Gambar 7. Contoh gambar Ilustrasi motor stepper dengan lilitan unipolar

- Motor Stepper Jenis Bipolar. Untuk motor stepper dengan lilitan bipolar, diperlukan sinyal pulsa yang berubah-ubah dari positif ke negatif dan sebaliknya. Jadi pada setiap terminal lilitan (A \& B) harus dihubungkan dengan sinyal yang mengayun dari positif ke negatif dan sebaliknya. Karena itu dibutuhkan rangkaian pengendali yang agak lebih kompleks dari pada rangkaian pengendali untuk motor unipolar. Maka motor stepper bipolar memiliki keunggulan dibandingkan dengan motor stepper unipolar dalam hal torsi yang lebih besar untuk ukuran yang sama. 


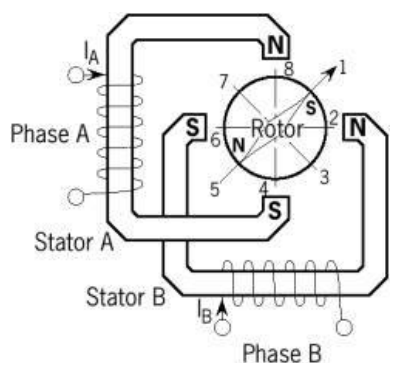

Gambar 8. Contoh gambar Ilustrasi motor stepper dengan lilitan bipolar

Motor stepper memiliki karakter yang lebih dibanding motor DC, seperti berikut: ${ }^{(9)}$

$\checkmark$ Sudut rotasi motor proporsional dengan pulsa input sehingga lebih mudah diatur.

$\checkmark$ Motor dapat langsung memberikan torsi penuh pada saat mulai bergerak.

$\checkmark$ Posisi dan pergerakan repetisinya dapat ditentukan secara presisi.

$\checkmark \quad$ Memiliki respon yang sangat baik terhadap start, stop dan berbalik perputaran.

$\checkmark$ Sangat realibel karena tidak adanya brush yang bersentuhan dengan rotor seperti pada motor DC.

$\checkmark$ Dapat menghasilkan perputaran yang lambat sehingga beban dapat dikopel langsung ke porosnya.

$\checkmark$ Frekuensi perputaran dapat ditentukan secara bebas, mudah pada range yang luas.

\section{Gerak Motor Stepper ${ }^{(1),(2)}$}

Ada beberapa mode pengaturan gerak motor stepper yaitu :

- Full : suatu mode motor stepper dimana pada setiap langkahnya (per-langkahnya) merupakan pergeseran maksimum antara rotor terhadap stator sehingga mode Full merupakan mode tercepat untuk melakukan pergeseran, perputaran namun memiliki kekurangan dari segi torsi yang dihasilkan.

- Half : dimana pada setiap pergeseran perlangkahnya merupakan setengah dari pergeseran yang dihasilkan oleh mode Full, sehingga mode Half memiliki kecepatan yang lebih lambat dari mode Full namun memiliki torsi yang lebih kuat.

Tabel 1. Pola dan cara kerja motor stepper

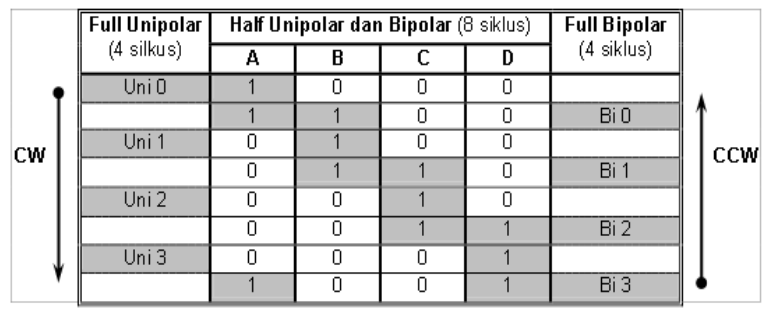

\section{Sistem Rotasi-Translasi}

Keluaran dari sistem kontrol elektronik pada umumnya yaitu gerakan rotasi dari motor, adapun dalam mekanik umumnya adalah translasi, sehingga dibutuhkan konversi dari gerak rotasi ke gerak translasi. Diantara teknik konversi dari gerak rotasi ke translasi adalah sebagai berikut:

* Timming Belt Actuator

Aktuator model ini menggunakan belt untuk mengubah gerak rotasi menjadi translasi.

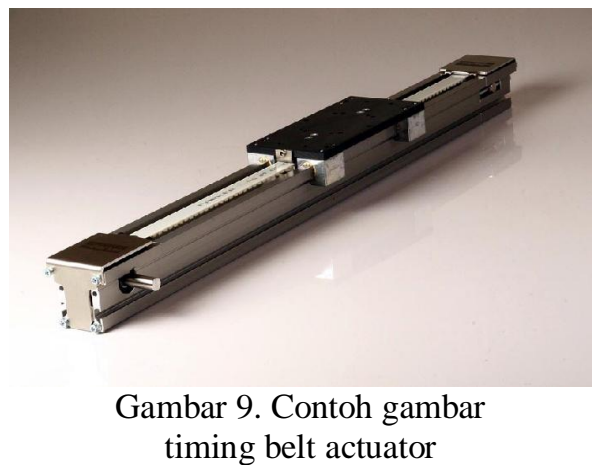

* Acme Screw atau Lead Screw

Acme screw atau lead screw merupakan pengubah gerakan dengan memanfaatkan gaya tekan akibat perputaran pada ulir. gaya inilah yang menyebabkan pergeseran pada axisnya. Pada prinsipnya sama seperti pasangan mur dan baut biasa. ketika mur/nut saya putar maka saya akan mendapatkan pergerakan linear dari bautnya (bolt). pada leadscrew biasanya dilengkapi dengan anti backlash yang biasanya dibuat dari bahan nylon atau kombinasi per dan kuningan.

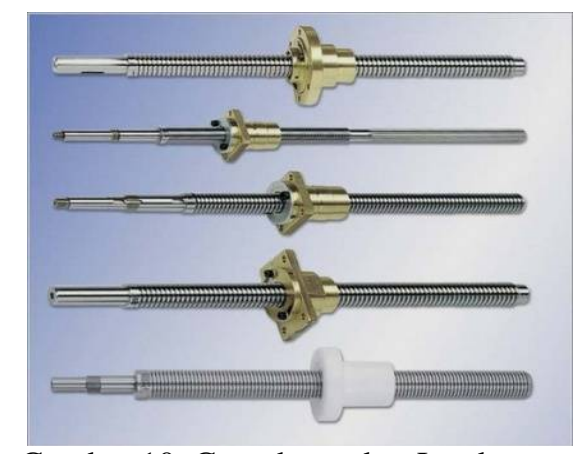

Gambar 10. Contoh gambar Lead screw

\section{* Ball Screw}

Seperti halnya lead screw, ballscrew pun juga menggunakan ulir. tetapi kalau yang ini diantara nut dan bolt terdapat ball (gotri) fungsinya untuk mengurangi koefisien gesek. ball screw ini merupakan pengubah gerak termahal kedua setelah multiple screw. 
* Rack and pinnion

Rack and pinnion merupakan kombinasi antara roda gigi pinion dan linear gear/rack. Prinsip kerjanya adalah mengubah putaran roda gigi pinnion yang diputar pada linear gear sehingga menghasilkan gerakan linear. Keuntungan penggunaan rack pinnion ini adalah kemungkinan pemasangan pada area pergeseran meja kerja yang panjang. kerugianya antaralain kepresisian yang tidak setinggi pengubah gerak lainya.

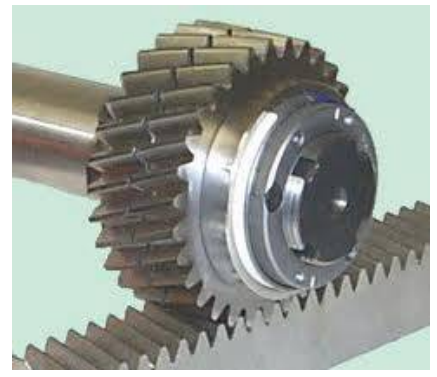

Gambar 11. Contoh gambar Rack and Pinnion

\section{Control Unit}

Ada banyak jenis control Unit yang beredar luas, ada yang dijual dalam bentuk hardware yang sudah jadi, ada pula software yang dapat diinstall ke PC. Merek control unit antara lain seperti:

- Fanuc

- Siemens

- Mitsubishi

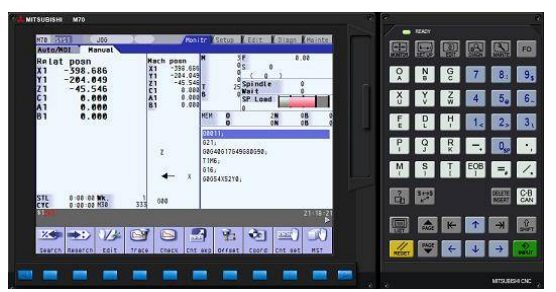

Gambar 12. Contoh gambar control unit merek mitsubishi

Adapun Software otomasi diantaranya adalah:

- $\mathrm{EMC2}$

- Mach3

- TuboCNC

\section{METODE PENELITIAN ${ }^{(6),(7),(8),(11),(12)}$ Pendekatan dan kerangka teoritis}

Otomasi berbasis axis menggunakan koordinat Cartesian sebagai acuan posisi, untuk 3-axis maka koordinat yang digunakan adalah $\mathrm{X}, \mathrm{Y}, \mathrm{Z}$. Posisi yang akan dikendalikan sebenarnya hanya 2-axis, yakni $\mathrm{X}$ dan $\mathrm{Y}$, akan tetapi naik turunnya "torch" perlu 1 sumbu untuk mengaturnya sehingga secara "Work Area" merupakan 2-axis, sementara secara kendali yang harus dibuat adalah 3-axis.

Untuk merealisasikan kendali 3-axis tersebut diatas, dibutuhkan penggerak yang dapat dikendalikan secara software dalam bentuk G-Code. Jenis penggerak elektrik yang dapat dikendalikan secara sederhana adalah motor stepper. Sementara putaran motor stepper dikendalikan dari software yang terinstall di PC. Gambaran sistem tersebut sebagai berikut:

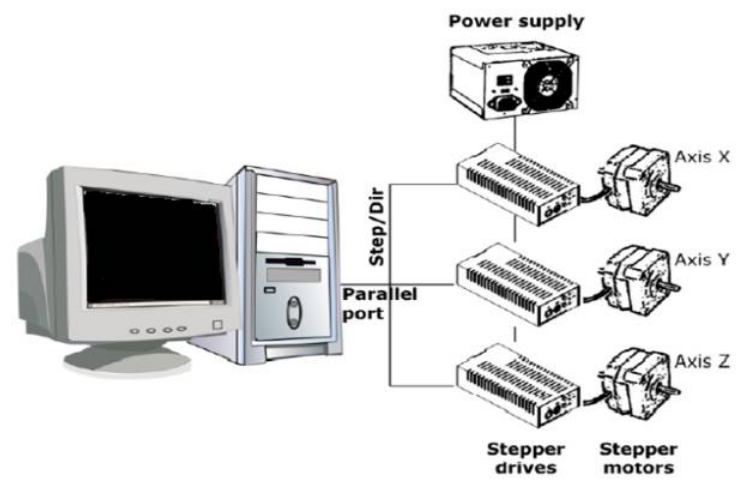

Gambar 13. Skema kerja kendali posisi dengan motor stepper

Cara kerja sistem yang dibangun adalah sebagai berikut:

- Software di PC membaca kode "G-Code".

- Software menerjemahkan dan mengirimkan perintah-perintah ke Driver motor stepper melalui port parallel.

- Driver motor stepper menggerakkan motor stepper sesuai G-Code yang dimasukkan.

- Motor stepper bergerak rotasi sesuai G-Code

- Ballscrew mengubah gerakan rotasi menjadi gerakan translasi.

- Posisi sesuai dengan G-code yang diinginkan

\section{Bahan dan Alat}

Bahan-bahan dan juga peralatan yang digunakan dalam kegiatan penelitian ini adalah:

- Personal Computer sebagai Control Unit

- Software kendali berbasis axis dan G-code

- Single axis robot 3 buah, untuk X, Y dan Z

- Motor Stepper 3 buah, untuk X, Y dan Z

- Driver Motor stepper

- Power Supply

- Relay dan sensor untuk rangkaian elektronik

- Plat-plat untuk membuat konstruksi

- Jangka sorong

- AVO Meter

- Peralatan bengkel

- Spidol dan kertas

- Toolset 


\section{Unit Elektronik $^{(11)}$}

Secara umum, rangkaian kendali yang dibuat sebagai berikut:

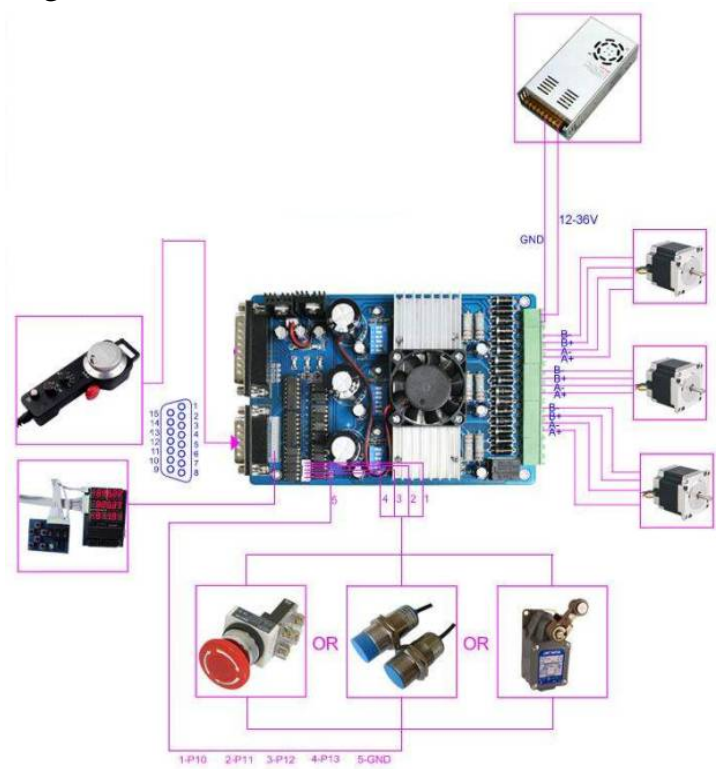

Gambar 14. Contoh rangkaian elektronik kendali posisi

\section{Seting Driver Motor Stepper}

Pada driver motor stepper, hal yang perlu di konfigurasi adalah:

- MicroStep Setting= $1 / 2$

- Port Input untuk = GND, E-STOP, X Home, Y Home dan Z Home.

- Port Output untuk = Motor X, Motor Y, Motor Z.

- Port Parallel $=$ Terhubung ke Port Parallel PC.

\section{Konstruksi}

Konstruksi mesin yang dibangun terdiri dari beberapa bagian antara lain :

- Meja kerja

- Holder torch

- Dudukan single axis robot untuk sumbu Y

- Dudukan single axis robot untuk sumbu Z

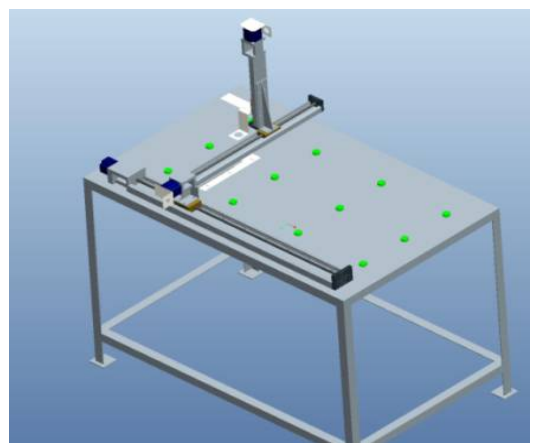

Gambar 15. Gambar konstruksi pilot model otomasi
Konstruksi yang sudah dilengkapi dengan motor, single axis robot dan sensor-sensornya sebagai berikut:

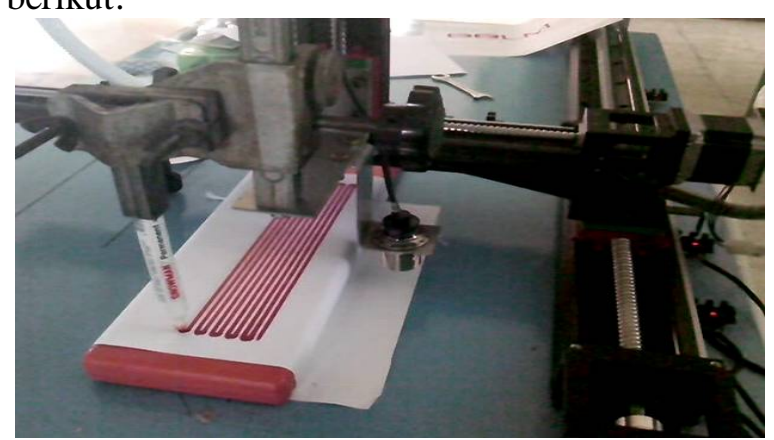

Gambar 16. Gambar mesin pengendali model otomasi 2-Axis yang sudah dilengkapi motor dan sensornya.

\section{Konfigurasi Software $^{(7),(8),(9)}$}

Yang harus dikonfigurasi adalah:

- Unit/satuan, seting satuan yang digunakan, satuan dapat mm (mili meter) atau inch.

- Port, adapun port yang digunakan adalah port 1 dengan address $0 x 378$.

- Pin pengendali motor:

$$
\begin{aligned}
& >\text { X Step }=1 \\
& >\text { X Direction =7 } \\
& >\text { X Step }=8 \\
& >\text { X Direction = 3 } \\
& >\text { X Step = 5 } \\
& >\text { X Direction = 4 }
\end{aligned}
$$

- Pin input:

$$
\begin{aligned}
& >\text { X Home }=12 \\
& >\text { Y Home }=11 \\
& >\text { Z Home }=10 \\
& >\text { Limiting Switch/E-Stop }=13
\end{aligned}
$$

- Parameter motor tuning:

$>$ Step per revolution $=40$

$>$ Velocity per $\mathrm{mm}=10002$

$>$ Acceleration in $\mathrm{mm} / \mathrm{sec}=41,675$

- Parameter homing:

\begin{tabular}{|c|c|c|c|}
\hline Axis & Reserved & $\begin{array}{c}\text { Home } \\
\text { Negatif }\end{array}$ & $\begin{array}{c}\text { Auto } \\
\text { Zero }\end{array}$ \\
\hline $\mathrm{X}$ & No & Yes & Yes \\
\hline Y & No & Yes & Yes \\
\hline$Z$ & No & Yes & Yes \\
\hline
\end{tabular}

Analisis Resiko Pelaksanaan Kegiatan

Resiko dalam pelaksanaan kegiatan ini adalah:

- Rangkaian elektronik dan sensor-sensor yang rusak, antara lain disebabkan karena:

$>$ Penyolderan yang terlalu lama.

Keliru dalam merangkai komponen.

- Kerusakan pada ballscrew penyebabnya:

Beban yang terlalu berat.

Terkena tekanan saat mesin over limit. 


\section{HASIL DAN PEMBAHASAN ${ }^{(3)}$}

Adapun uji coba yang dilakukan dalam kegiatan penelitian ini diantaranya adalah:

1. Uji coba akurasi gerakan

Uji coba yang akan dilakukan yaitu dengan cara memasukan kode G-Code: G0x100 yang berarti menggerakkan kearah sumbu $X$ sepanjang $100 \mathrm{~mm}(10 \mathrm{~cm})$. Hasil pengukuran dengan jangka sorong menunjukkan bahwa ujung referensi koordinat bergerak sepanjang $100 \mathrm{~mm}$ $(10 \mathrm{~cm})$, sama dengan kode logic yang dimasukkan ke software.

\section{Uji coba homing}

Uji coba ini untuk memastikan apakah ketika proses homing dilakukan, mesin menuju ke titik referensi $(0,0,0)$. Uji coba menghasilkan:

> Pertama, holder bergerak naik ke atas (z negative) sampai limiting switch,

$>$ Kedua, holder bergerak ke arah y negatif sampai menyentuh limiting switch,

$>$ Ketiga, terakhir holder bergerak ke arah $\mathrm{x}$ negative sampai menyentuh limiting switch Sehingga pada akhirnya, mesin mencapai posisi $(0,0,0)$ dengan sempurna

3. Uji coba gerakan zig-zag/gergaji

Gerakan ini merupakan simulasi proses pengelasan dimana pada proses pengelasan umumnya dengan pola zig-zag atau gergaji. Uji coba ini dengan cara memasukkan kode G-Code, maka hasil pengujian seperti terlihat dalam gambar berikut ini:

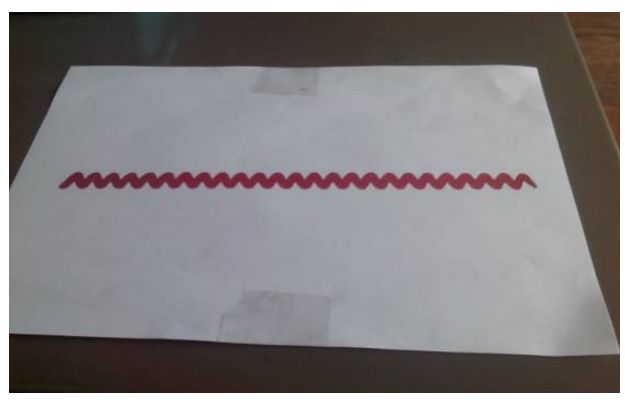

Gambar 17. Contoh gambar simulasi hasil uji coba gerakan zig-zag/gergaji

4. Uji coba simulasi gerakan proses hardfacing. Gerakan ini merupakan simulasi proses hardfacing dimana torch bergerak teratur 'mengarsir' object sehingga menjadi penuh. Uji coba ini dengan cara memasukkan kode G-Code, maka hasil pengujian seperti terlihat dalam gambar berikut ini:

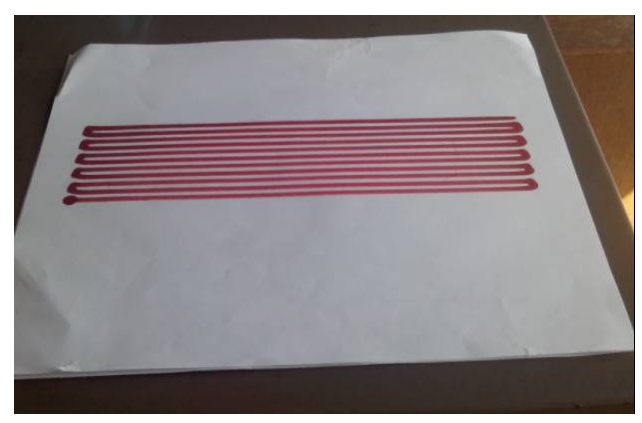

Gambar 18. Contog gambar simulasi hasil uji coba gerakan hardfacing

5. Uji coba gerakan pola tulisan

Gerakan ini untuk uji coba gerakan yang lebih rumit, berupa gerakan $\mathrm{X}$ dan $\mathrm{Y}$ secara bersamaan, uji coba ini untuk menulis kata "BBLM" dengan spidol yang dipasang di mesin otomasi 2-axis. Uji coba ini dengan cara memasukkan kode G-Code, maka hasil pengujian seperti terlihat dalam gambar berikut ini:

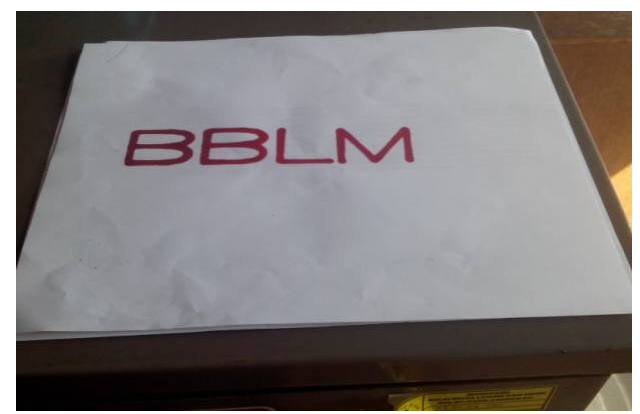

Gambar 19. Contoh gambar simulasi hasil uji coba gerakan pola tulisan

\section{PEMBAHASAN}

Setelah dilakukan uji coba pada simulasi dalam kegiatan penelitian ini, maka didapatkan hasil dan pembahasan sebagai berikut:

1. Uji coba akurasi gerakan

Mesin dapat bergerak sesuai dengan apa yang diinginkan, contohnya G-code yang berisi gerakan $\times 100 \mathrm{~mm}$, maka mesin agar bergerak $100 \mathrm{~mm}$ juga. Hal ini menunjukkan bahwa:

1. Seting parameter di software sudah benar

2. Ballscrew akurat.

2. Uji coba proses homing

Mesin dapat 'parkir' ke posisi referensi mesin yaitu pada koordinat $(0,0,0)$. Hal ini menujukkan bahwa:

1. Seting parameter di software sudah benar

2. Ballscrew akurat. 
3. Uji coba gerakan zig-zag

Mesin dapat bergerak sesuai dengan G-code yang dimasukkan berupa gerakan zig-zag, pada prinsipnya gerakan apapun berbasis 3-axis (X/Y/Z) dapat dilakukan asalkan dalam format G-Code.

4. Uji coba simulasi gerakan hardfacing

Mesin dapat bergerak sesuai dengan G-code yang dimasukkan berupa gerakan untuk simulasi hardfacing, pada prinsipnya gerakan apapun berbasis 3-axis (X/Y/Z) dapat dilakukan asalkan dalam format G-Code.

5. Uji coba gerakan pola tulisan

Mesin dapat bergerak sesuai dengan g-code yang dimasukkan berupa gerakan untuk membentuk pola tulisan, pada prinsipnya gerakan serumit apapun selama berbasis 3-axis (X/Y/Z) dapat dilakukan asalkan dalam format G-Code.

\section{KESIMPULAN DAN SARAN}

ini adalah:

Kesimpulan yang didapat dari penelitian

1. Otomasi berbasis axis dapat menggunakan software berbasis PC sebagai alternatif penggunaan control unit yang mahal.

2. Gerakan berbasis 3-axis apapun dapat dilakukan dengan menggunakan code "G-Code"

3. Jika teknologi kendali ini diterapkan pada proses produksi masal, misalnya pada produksi yang membutuhkan otomasi las dapat meningkatkan kapasitas produksi dan meningkatkan kualitas produksi.

Adapun saran-saran yang mungkin dapat dikembangkan dari kegiatan penelitian ini:

1. Hasil penelitian pada teknologi kendali ini dapat dikembangkan untuk proses-proses produksi yang membutuhkan otomasi gerakan berbasis axis lainnya seperti: otomasi untuk flame cutting, CNC dan pembuatan pola pengecoran.

2. Dapat dilakukan pengembangan penggunaan variasi hardware yang digunakan, misalnya:
a. Penggunaan motor servo.
b. Penggunaan motor konsumsi dengan daya yang lebih besar.
c. Penggunaan driver motor yang lain.

\section{UCAPAN TERIMA KASIH}

Penulis mengucapkan terima kasih yang sebesar-besarnya pada semua pihak yang telah membantu dalam penelitian ini, khususnya kepada Bapak Ir. Eddy Siswanto, MAM. Selaku Kepala Balai Besar Logam dan Mesin.

\section{DAFTAR PUSTAKA}

1. Afnani, V.V, 2005. Stepper Motors (Fundamentals, Application and Design), Ed.2, New Age International (P) Publisher, New Delhi, India.

2. Budiharto, Widodo, 2008. Panduan Praktikum Microcontroler AVR ATMegal6, cetakan I, hal. 80-83, PT. Elex Media Komputindo, Jakarta, Indonesia.

3. BT Gibson, DH Lamlein, TJ Prater, CD Cox, 2013. Friction Stir Welding ; Process, Automation and Control, Jurnal of Manufacturing Processes, Elseveir Ltd, Oxford, United Kingdom.

4. Sastra M, Suparno, 2009. Permodelan 2D dan 3D dengan Autocad, Cetakan I, hal. 195-197, PT. Elex Media Komputindo, Jakarta, Indonesia.

5. W. Liou, Frank, 2008. Rapid Prototyping and Engineering Apllications, CPC Press, Inc.

6. Art Soft, Mach3Mill Release 1.84, 2006. The Old, Gear, Way of Co-ordinating Motion On Mill Table and Rotary Axis, www.micro-machine-shop.com/Mach3Mill_ 1.84.pdf (download tgl 21 Mei 2014).

7. LinuxCNC, EMC2 user manual, 2011. The Enchenced Machine Controller, www.linuxcnc.org/docs/2.4/EMC2_User_ Manual.pdf

8. http://www.micro-machine-shop.com/ Mach3Mill_1.84.pdf

9. http://elektronika-dasar.web.id/teorielektronika/motor-stepper

10. http://id.wikipedia.org/wiki/Teknik_otomasi (download tgl 21 Mei 2014).

11. Univelop 3-axis TB6560 CNC Driver Board, V2.0 User Manual, www.cncgeeker.com/images/manual/cnc/ 3axisTB6560cncdrivecncgekeer.pdf

12. 3-axis TB6560 CNC Driver Board User Manual, www.cnc_stepperonline.com/ download/pdf/3_axis_TB6560_CNC_Driver _Board_User_Manual.pdf 